\title{
Article \\ Structure-Based Functional Analysis of a Hormone Belonging to an Ecdysozoan Peptide Superfamily: Revelation of a Common Molecular Architecture and Residues Possibly for Receptor Interaction
}

\author{
Yun-Ru Chen ${ }^{1}$, Nai-Wan Hsiao ${ }^{2}$, Yi-Zong Lee ${ }^{1,3}$, Shiau-Shan Huang ${ }^{2}$, Chih-Chun Chang ${ }^{2}$, Jyuan-Ru Tsai ${ }^{4}$, \\ Hui-Chen Lin ${ }^{4}\left(\mathbb{D}\right.$, Jean-Yves Toullec ${ }^{5}$, Chi-Ying Lee ${ }^{2, * \mathbb{D}}$ and Ping-Chiang Lyu ${ }^{1,6, * \mathbb{D}}$
}

check for updates

Citation: Chen, Y.-R.; Hsiao, N.-W.; Lee, Y.-Z.; Huang, S.-S.; Chang, C.-C.; Tsai, J.-R.; Lin, H.-C.; Toullec, J.-Y.; Lee, C.-Y.; Lyu, P.-C. Structure-Based Functional Analysis of a Hormone Belonging to an Ecdysozoan Peptide Superfamily: Revelation of a

Common Molecular Architecture and Residues Possibly for Receptor Interaction. Int. J. Mol. Sci. 2021, 22, 11142. https://doi.org/10.3390/ ijms222011142

Academic Editor: Grazia Chiellini

Received: 28 August 2021

Accepted: 12 October 2021

Published: 15 October 202

Publisher's Note: MDPI stays neutral with regard to jurisdictional claims in published maps and institutional affiliations.

Copyright: () 2021 by the authors Licensee MDPI, Basel, Switzerland. This article is an open access article distributed under the terms and conditions of the Creative Commons Attribution (CC BY) license (https:// creativecommons.org/licenses/by/ $4.0 /)$.
1 Institute of Bioinformatics and Structural Biology, National Tsing Hua University, Hsinchu 300044, Taiwan; chenyrusa@gmail.com (Y.-R.C.); s942545@go.thu.edu.tw (Y.-Z.L.)

2 Department of Biology, National Changhua University of Education, Changhua 500207, Taiwan; nady@cc.ncue.edu.tw (N.-W.H.); hss.33333@gmail.com (S.-S.H.); u9120037@imss.hshs.tyc.edu.tw (C.-C.C.)

3 Instrument Center, National Tsing Hua University, Hsinchu 300044, Taiwan

4 Department of Life Science, Tunghai University, Taichung 407224, Taiwan; jrtsaibio@thu.edu.tw (J.-R.T.); hclin@thu.edu.tw (H.-C.L.)

5 Faculté de Sciences, CNRS, UMR 7144, Adaptation et Diversité en Milieu Marin, AD2M, Station Biologique de Roscoff, Sorbonne Université, 29682 Roscoff, France; jean-yves.toullec@sb-roscoff.fr

6 Department of Medical Sciences, National Tsing Hua University, Hsinchu 300044, Taiwan

* Correspondence: bicylee@cc.ncue.edu.tw (C.-Y.L.); pclyu@mx.nthu.edu.tw (P.-C.L.);

Tel.: +886-4724-7756 (C.-Y.L.); +886-3574-2762 (P.-C.L.); Fax: +886-4721-1156 (C.-Y.L.); +886-3571-5934 (P.-C.L.)

Abstract: A neuropeptide (Sco-CHH-L), belonging to the crustacean hyperglycemic hormone (CHH) superfamily and preferentially expressed in the pericardial organs (POs) of the mud crab Scylla olivacea, was functionally and structurally studied. Its expression levels were significantly higher than the alternative splice form ( $\mathrm{ScO}-\mathrm{CHH})$ in the $\mathrm{POs}$, and increased significantly after the animals were subjected to a hypo-osmotic stress. Sco-CHH-L, but not Sco-CHH, significantly stimulated in vitro the $\mathrm{Na}^{+}, \mathrm{K}^{+}$-ATPase activity in the posterior (6th) gills. Furthermore, the solution structure of Sco-CHH-L was resolved using nuclear magnetic resonance spectroscopy, revealing that it has an $N$-terminal tail, three $\alpha$-helices $\left(\alpha 2, \mathrm{Gly}^{9}-\mathrm{Asn}^{28} ; \alpha 3, \mathrm{His}^{34}-\mathrm{Gly}^{38}\right.$; and $\left.\alpha 5, \mathrm{Glu}^{62}-\mathrm{Arg}^{72}\right)$, and a $\pi$-helix $\left(\pi 4, \mathrm{Cys}^{43}-\mathrm{Tyr}^{54}\right)$, and is structurally constrained by a pattern of disulfide bonds $\left(\mathrm{Cys}^{7}-\mathrm{Cys}^{43}\right.$, $\mathrm{Cys}^{23}-\mathrm{Cys}^{39}$, and $\mathrm{Cys}^{26}{ }^{2} \mathrm{Cys}^{52}$ ), which is characteristic of the $\mathrm{CHH}$ superfamily-peptides. Sco-CHH$\mathrm{L}$ is topologically most similar to the molt-inhibiting hormone from the Kuruma prawn Marsupenaeus japonicus with a backbone root-mean-square-deviation of $3.12 \AA$. Ten residues of Sco-CHH-L were chosen for alanine-substitution, and the resulting mutants were functionally tested using the gill $\mathrm{Na}^{+}, \mathrm{K}^{+}$-ATPase activity assay, showing that the functionally important residues (I2, F3, E45, D69, I71, and G73) are located at either end of the sequence, which are sterically close to each other and presumably constitute the receptor binding sites. Sco-CHH-L was compared with other members of the superfamily, revealing a folding pattern, which is suggested to be common for the crustacean members of the superfamily, with the properties of the residues constituting the presumed receptor binding sites being the major factors dictating the ligand-receptor binding specificity.

Keywords: neuropeptide; peptide hormone; structure-function; $\mathrm{Na}+\mathrm{K}+-\mathrm{ATPase}$; osmoregulation; tertiary structure; mutant; brachyuran

\section{Introduction}

The crustacean hyperglycemic hormone $(\mathrm{CHH})$ peptide superfamily, consisting of a group of structurally and functionally diverse peptides, has long attracted research interest for the study of functional diversification through structural changes [1-10]. Peptides 
constituting the superfamily, once thought to be restricted to crustaceans, have now been clearly shown to be present across clades of Ecdysozoa [11].

Inferences through classical ablation and replacement experiments suggested the presence in the eyestalk of crustaceans of an array of humoral factors-presumptive hormones regulating metabolism, reproduction, molting and growth, cardiac activity, color changes, etc. [12] —attesting to the importance of the X-organ/sinus gland (XO/SG) complex, a neuroendocrine tissue in the eyestalk, in the regulation of crustacean physiology. Most of the presumptive factors have since been biochemically purified and characterized, and their biological activity confirmed; these include a group of sequence-related peptides- $\mathrm{CHH}$ (the prototypic member of the superfamily), molt-inhibiting hormone (MIH), gonad-inhibiting hormone (GIH) or vitellogenesis-inhibiting hormone (VIH), and mandibular organ-inhibiting hormone (MOIH) [11], that once constituted the $\mathrm{CHH}$ family [13-15]. Identification in the locust Schistocerca gregaria of ion transport peptide (ITP), which stimulates ileal salt and water reabsorption, as an insect member [16], expanded for the first time the existence of the superfamily peptides to other arthropod groups. Studies utilizing approaches of in silico data mining further extended its presence to several representative ecdysozoan clades $[7,17,18]$. Recent additions to the superfamily include latrodectin peptides and HAND (helical arthropod-neuropeptide-derived) toxins in the venoms of spiders and centipedes $[8,10]$.

A structural signature of the $\mathrm{CHH}$ superfamily is the connectivity of six invariant cysteine residues forming a unique pattern of disulfide bonds (C1-C5, C2-C4, and C3-C6). Further, members of the $\mathrm{CHH}$ superfamily are placed into one of two groups, Type I or Type II, according mainly to the characteristics of the peptide precursors and its mature peptides. A Type-I peptide (CHH, ITP, or their long alternative splice form (CHH-L or ITP-L, see below)) is characterized by having a precursor consisting of a signal peptide, a precursor-related peptide, and a mature peptide, while a Type-II peptide $(\mathrm{MIH}, \mathrm{VIH}$, or $\mathrm{MOIH}$ ) by having a precursor consisting of a signal peptide and a mature peptide, without an intervening precursor-related peptide [11] With regard to the mature peptide, the shortsplice form of Type-I peptides (CHH and ITP), but not CHH-L or ITP-L, are C-terminally amidated, which is critically important for the biological activity, while both short- and long-splice forms are $\mathrm{N}$-terminally pyroglutaminated. The majority of Type-II peptides are free at both ends, with some exceptional VIHs and MIHs being C-terminally amidated [11]. Analysis of sequence motifs revealed that two groups of the peptides (corresponding to the Type-I and Type-II peptides) can be differentiated by group-specific motifs found at the $\mathrm{N}$ - and $\mathrm{C}$-termini of the peptides, while the motifs in the center part of the sequence are common to all peptides [1].

$\mathrm{CHH}$-superfamily peptides expressed in crustacean tissues had initially been identified and characterized each using a distinct bioassay and thus named following the biological function the assay is based on. However, it is now widely recognized that these peptides are usually pleiotropic in biological activity and in some instances are active in the same assay, i.e., functional overlap. For example, while $\mathrm{CHH}$ is well established for being involved in metabolism regulation [19-21] and in particular in stress-induced hyperglycemia, it has also been shown to be active in repressing ecdysteroidogenesis in the Y-organ (i.e., MIH activity) and methyl farnesoate synthesis in the mandibular organ (i.e., MOIH activity) [11]. It has been proposed that evolution of the $\mathrm{CHH}$-superfamily peptides involved events of duplication of an ancestral gene, which may have encoded a pleiotropic peptide similar to current $\mathrm{CHHs}$, leading to two main paralogous lineages (Type-I and Type-II peptides). The two lineages during the course of evolution may have partitioned the ancestral functions via a process known as subfunctionalization, with the Type-II paralogous lineages evolved to peptides with more specialized functions such as MIHs or VIHs, while Type-I lineages to peptides retaining to a certain degree the functional pleiotropy of the ancestral peptide [7].

Functional and structural polymorphism of the $\mathrm{CHH}$-superfamily is further diversified by a post-transcriptional process-RNA alternative splicing. Thus, for crustacean chh gene, 
there are long- and short-splice forms, which share the same amino acid sequence for the first forty residues but differ significantly in the rest of the sequences that are encoded by different exons [11]. The peptide of long-splice form derived from chh gene, the $\mathrm{CHH}-$ L peptide, is functionally less characterized than its short form counterpart, $\mathrm{CHH}$. In several species including the mud crab Scylla olivacea, where $\mathrm{CHH}$ and $\mathrm{CHH}-\mathrm{L}$ have been functionally tested and compared, $\mathrm{CHH}-\mathrm{L}$ neither elicited in vivo hyperglycemic response nor exerted in vitro inhibitory effect on the Y-organ [22-24]. The specific functions of $\mathrm{CHH}-\mathrm{L}$, which is usually preferentially expressed in non-eyestalk tissues, remain to be characterized.

Studies using recombinant mutants of the $\mathrm{CHH}$-superfamily peptides to pinpoint functionally critical residues have been carried out for MIH of Marsupenaeus japonicus [4], CHHs of S. olivacea [9], and ITP of S. gregaria [2,5], with a general consensus that functionally important residues are located at the $N$-terminal and $C$-terminal ends of the peptides. The tertiary structure of two crustacean CHH-superfamily peptides, Pej-MIH and Pej-SGP-I-Gly (a glycine-extended precursor of $\mathrm{CHH}$ from M. japonicus), has been resolved [25,26], as well as that of HAND toxins in the venom of spiders and centipedes [10]. Interestingly, despite Pej-MIH and HAND toxins being otherwise structurally similar, the structure of the latter peptides lack a $C$-terminal helix $(\alpha 5)$, which is present in the Pej-MIH, a structural difference thought to be related to the functional differences between the two types of peptides [10]. Moreover, unexpected dissimilarity between the structure of Pej-MIH and Pej-SGP-I-Gly, particularly at the backbone fold at the C-terminus with Pej-SGP-I-Gly lacking an $\alpha 5$, was conspicuously noted [26].

Pericardial organs (POs) are a pair of neurohemal organs, located in the venous cavity surrounding the heart [27], synthesizing and secreting into hemolymph amine and peptide hormones $[28,29]$. One of the physiological processes regulated by POs is osmoregulation $[28,30]$. In the present study, Sco-CHH-L, a CHH-L peptide preferentially expressed in the POs of the mud crab Scylla olivacea [31], was functionally and structurally characterized. Sco-CHH-L transcript levels were significantly elevated when animals were facing a hypoosmotic stress. We further report that Sco-CHH-L stimulated in vitro the $\mathrm{Na}^{+} / \mathrm{K}^{+}$-ATPase activity in the posterior gills, establishing a specific role for the peptide in the osmoregulation of marine brachyurans. The tertiary structure of Sco-CHH-L was resolved using nuclear magnetic resonance spectroscopy. Functional test of alanine-substituted Sco-CHH$\mathrm{L}$ mutants was performed using the $\mathrm{Na}^{+}, \mathrm{K}^{+}$-ATPase activity assay showing that several functionally critical residues at both ends of the sequence presumably constituting the receptor binding/activation sites. Comparison of Sco-CHH-L with other crustacean peptides, especially the Pej-MIH, suggests a structural architecture likely common to crustacean members of the superfamily.

\section{Results}

2.1. Sco-CHH-L and Sco-CHH Transcript, and Protein Expression Levels in the Pericardial Organs

We performed semi-quantitative real-time PCR on the cDNA samples derived from the pericardial organs (POs) with transcript-specific primers to determine the levels of Sco-CHH-L and Sco-CHH transcript; data showed that Sco-CHH-L expressed at levels significantly higher (2.5-fold) than Sco-CHH (Figure S1A). At the protein levels, an enzymelinked immunosorbent assay showed that levels of Sco-CHH-L were significantly higher (25.6-fold) than those of Sco-CHH (3.33 vs. 0.13 pmol) (Figure S1B).

\subsection{Pattern of Changes in Sco-CHH-L and Sco-CHH Transcript Levels under Osmotic Stresses}

Sco-CHH transcript levels in the PO from the 25 ppt-acclimated crabs did not significantly change from the pre-transfer levels $(0 \mathrm{~h})$ when the animals were subjected to either hypo-osmotic (transferred to $5 \mathrm{ppt}$ ) or hyper-osmotic (transferred to $45 \mathrm{ppt}$ ) stress at any time point examined (Figure S2). Sco-CHH-L transcript levels in the $25 \mathrm{ppt}$-acclimated crabs did not significantly change from the pre-transfer levels when subjected to hyper-osmotic 
stress at any time, whereas the levels significantly increased in the animals subjected to hypo-osmotic stress at $12 \mathrm{~h}$ post-transfer (Figure S2).

\subsection{Characterization of Wild-Type and Mutated Sco-CHH-L Peptides}

Recombinant proteins were expressed using a bacterial expression system, followed by a refolding reaction, and high-performance liquid chromatography (HPLC)-purification. Results of mass spectrometric analysis of the purified recombinant Sco-CHH-L peptides are listed in Table 1, which shows that the observed mass of each peptide is in close agreement with its theoretical value. In addition, the circular dichroism (CD) spectrum of each peptide exhibited negative bands at 208 and $222 \mathrm{~nm}$ (Figure S3); the calculated $\alpha$-helical content ranged between $26.2 \sim 40.0 \%$ (Table 1 ). The significant reduction in $\alpha$-helical content in G73A Sco-CHH-L is most likely due to the replacement of Gly73, a capping glycine residue at the carboxyl end of an $\alpha$ helix [32], by an alanine residue.

Table 1. Identification and characterization of recombinant wild-type and alanine-substituted peptides.

\begin{tabular}{cccc}
\hline Peptide & Theoretical Mass (Da) & Observed Mass (Da) & $\boldsymbol{\alpha}$-Helix (\%) \\
\hline Sco-CHH & 8527.9 & 8528.0 & 47.0 \\
Sco-CHH-L & 8626.8 & 8626.0 & 40.0 \\
I2A & 8584.7 & 8584.0 & 36.1 \\
F3A & 8550.7 & 8551.0 & 31 \\
V41A & 8598.8 & 8598.3 & 38.5 \\
E45A & 8568.8 & 8568.0 & 38.0 \\
N60A & 8583.8 & 8584.5 & 28.1 \\
E62A & 8568.8 & 8568.5 & 37.5 \\
E63A & 8568.8 & 8568.5 & 37.1 \\
D69A & 8582.8 & 8583.0 & 39.1 \\
I71A & 8584.7 & 8584.0 & 35 \\
G73A & 8640.9 & 8642.0 & 26.2 \\
\hline
\end{tabular}

\subsection{Effects of Sco-CHH and Sco-CHH-L on $\mathrm{Na}^{+}, \mathrm{K}^{+}$-ATPase Activity in Posterior Gills}

The wild-type Sco-CHH-L peptide stimulated $\mathrm{Na}^{+}, \mathrm{K}^{+}$-ATPase activity in the posterior gills (gill 6), with the maximal effect being attained at $125 \mathrm{pM}$ (Figure 1A). On the other hand, Sco-CHH with an amidated $\mathrm{C}$-terminus did not exert any significant effect, even at high doses (500 or $5000 \mathrm{pM}$ ) (Figure 1B).

A

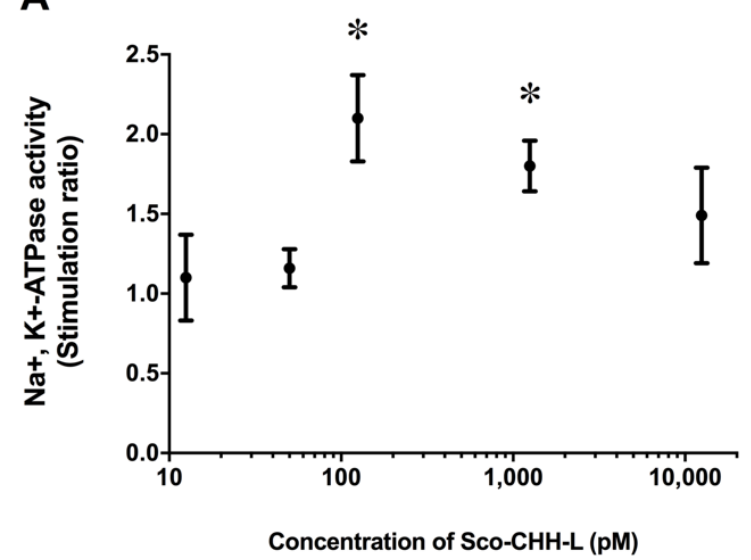

B

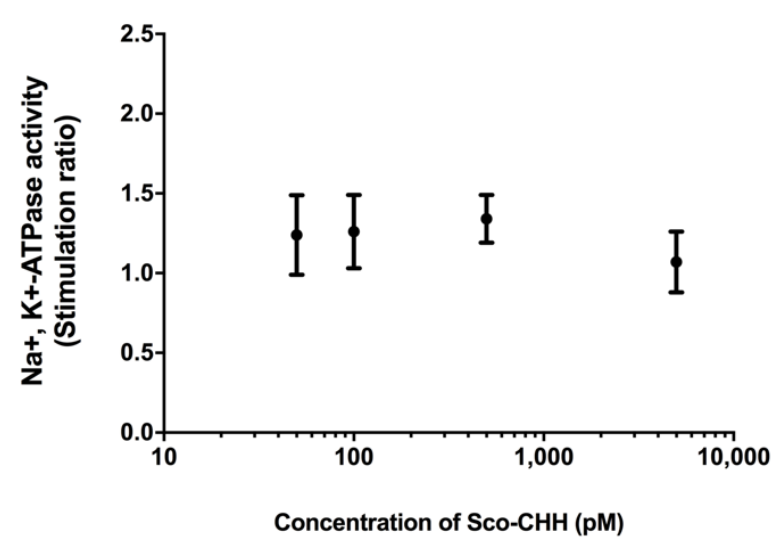

Figure 1. In vitro effects of Sco-CHH-L and Sco-CHH on the $\mathrm{Na}^{+}, \mathrm{K}^{+}$-ATPase activity in posterior gills of the mud crab Scylla olivacea. The posterior gills (gill 6) were dissected and received perfusion of (A) Sco-CHH-L (12.5, 50.0, 125.0, 1250.0, and 10,000 pM) or (B) Sco-CHH (50.0, 100.0, 500.0, and 5000.0 pM). Data are means \pm SEM and expressed as the stimulation ratio. $n=4$ for each treatment. The asterisk $\left(^{*}\right)$ indicates significantly different from vehicle control (saline treatment) at $5 \%$ level. 


\subsection{Solution Structure of Sco-CHH-L}

We have finished near complete backbone assignments of Sco-CHH-L excepting those for Gln1, Ile2, Phe3, and Asp4 in the N-terminal region. The NMR restraints structural statistics are summarized in Table S1. The initial three-dimensional structures of Sco-CHH$\mathrm{L}$ were calculated from a total of 1267 restraints including 1123 NOE-derived distance constraints (338 intra-residues, 337 sequential, 371 medium ranges, and 77 long-range NOEs), 50 hydrogen bond restraints, and 94 dihedral angle restraints ( $\varphi: 47, \psi: 47)$. In the well-defined regions (res. 9-28, 34-38, 43-54, and 62-72), the RMSD values of the ensemble conformations (Figure 2A) were $0.54 \pm 0.14 \AA$ for backbone and $1.43 \pm 0.27 \AA$ for heavy atoms (Table S1). In the Ramachandran plot for the ten selected structures, most residues are in the most favored regions $(75.4 \%)$ or additionally allowed regions $(23.2 \%)$, with $1.4 \%$ of the residues in the generously allowed regions; no residue is in the disallowed regions (Table S1).

A

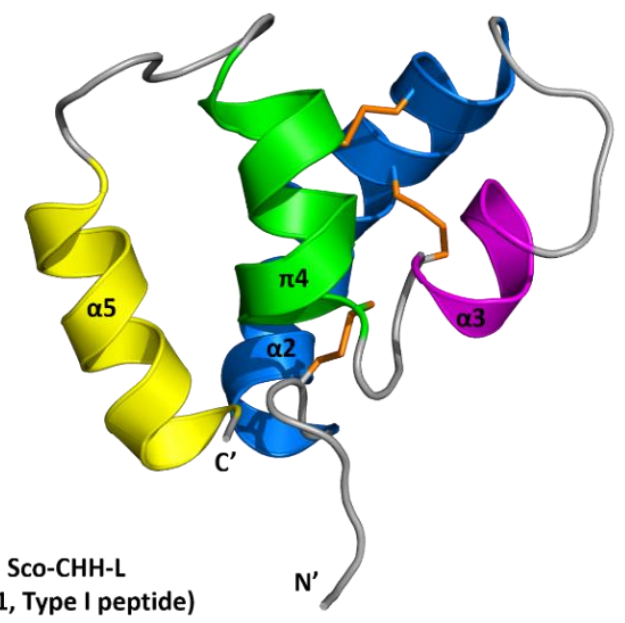

C

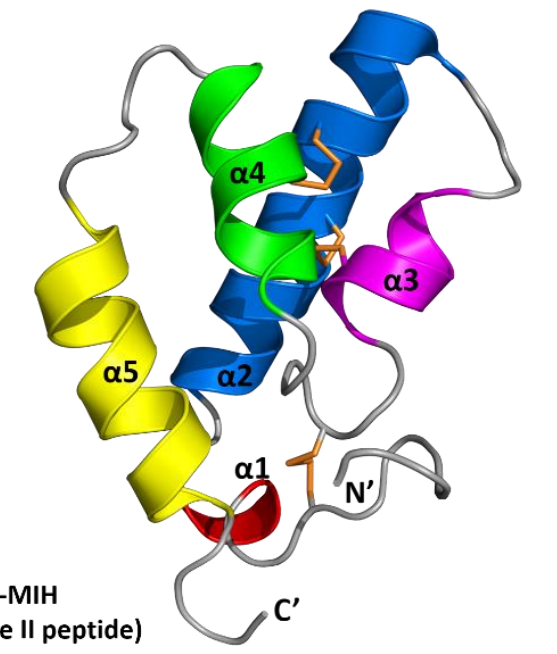

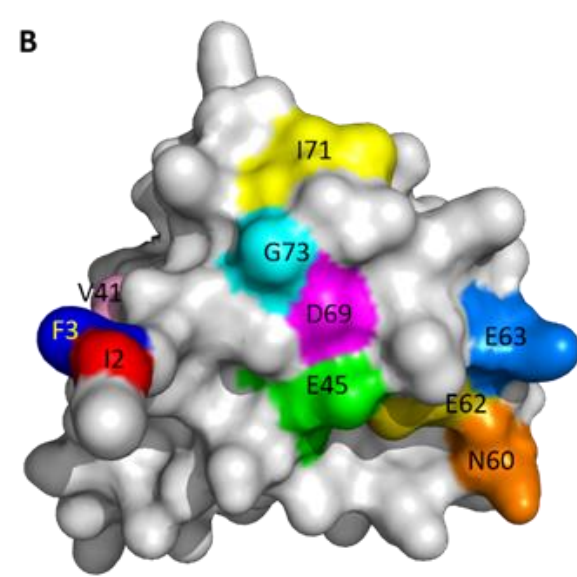

D

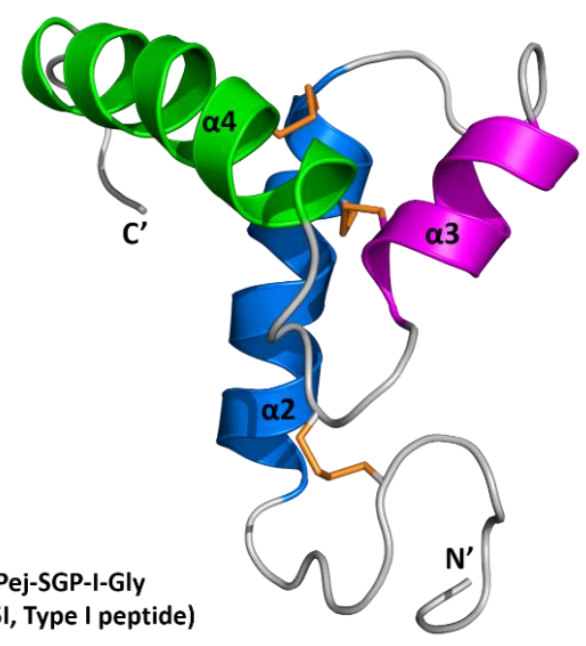

Figure 2. Structure of Sco-CHH-L and its comparison with other CHH/ITP peptides. (A) Ribbon and (B) surface structure of Sco-CHH-L, and ribbon structure of (C) Pej-MIH and (D) Pej-SGP-I-Gly. The helices, $N$ - and C-terminus $\left(\mathrm{N}^{\prime}\right.$ and $\left.\mathrm{C}^{\prime}\right)$ are labeled. (B) Location of the ten residues that were alanine-substituted in the Sco-CHH-L mutants are labeled on the surface structure. Note that (B) is not viewed from the same angle as (A), but is rotated so that all residues are visible. $(\mathbf{A}, \mathbf{C}, \mathbf{D})$ Orange sticks indicate disulfide bridging.

The solution structure of Sco-CHH-L contains an $N$-terminal tail, three $\alpha$-helices $(\alpha 2$, $\mathrm{Gly}^{9}-\mathrm{Asn}^{28} ; \alpha 3, \mathrm{His}^{34}-\mathrm{Gly}^{38}$; and $\left.\alpha 5, \mathrm{Glu}^{62}-\mathrm{Arg}^{72}\right)$, a $\pi$-helix $\left(\pi 4, \mathrm{Cys}^{43}-\mathrm{Tyr}^{54}\right)$ between $\alpha 3$ and $\alpha 5$, and three loops between the helices $(\alpha 2-\alpha 3, \alpha 3-\pi 4$, and $\pi 4-\alpha 5)$ (Figures 2 and 3 ). The first four unassigned residues located in $N$-terminal loop region are inherently flexible. Sco-CHH-L contains six cysteine residues forming three disulfide bonds $\left(\mathrm{Cys}^{7}-\mathrm{Cys}^{43}\right.$, 
$\mathrm{Cys}^{23}-\mathrm{Cys}^{39}$, and $\mathrm{Cys}^{26}-\mathrm{Cys}^{52}$ ), as confirmed by NMR spectrum (Figure S4), connecting the $N$-terminal tail and $\pi 4 ; \alpha 2$ and the loop between $\alpha 3$ and $\pi 4$; and $\alpha 2$ and $\pi 4$, respectively. Three aromatic residues in the hydrophobic core of a HAND toxin (Ta1a) important for packing of the structure [10] are conserved in the Sco-CHH-L as Phe ${ }^{16}, \mathrm{Phe}^{44}$, and $\mathrm{Phe}^{49}$ (Figure 4). Comparison of the structure of Sco-CHH-L with that of Pej-MIH (Protein Dada Bank: 1J0T), a type II peptide of the CHH superfamily, using Swiss-PdbViewer [33] showed a backbone root mean-square deviation (RMSD) of $3.12 \AA$, whereas comparison with PejSGP-I-Gly (PDB: 5B5I), the precursor of a Marsupenaeus japonicas CHH, yielded a RMSD of $4.12 \AA$ A

\subsection{Functionally Important Residues of Sco-CHH-L}

To elucidate the residues of Sco-CHH-L important for stimulating the $\mathrm{Na}^{+}, \mathrm{K}^{+}$-ATPase activity in gill 6, ten alanine-substituted Sco-CHH-L peptides (I2A, F3A, V41A, E45A, N60A, E62A, E63A, D69A, I71A, and G73A Sco-CHH-L) were produced. The residues chosen for substitution are those with side chains located on the surface of the Sco-CHH-L structure (Figure 2B). Ile ${ }^{2}$ and $\mathrm{Phe}^{3}$ are two highly conserved residues in the $\mathrm{N}$-terminus of Type-I peptides and have been shown to be critical for CHH and ITP functions (41-43); $\mathrm{Asn}^{60}$ and Asp ${ }^{69}$ were located, respectively in loop 3 and $\alpha-5$ of Sco-CHH-L, positions where the residue property in $\mathrm{CHH}-\mathrm{L}$ peptides was different to that in $\mathrm{CHH}$ peptides (i.e., $\mathrm{Asn}^{60}$ vs. Asp $^{60}$ and Asp $^{69}$ vs. Ile ${ }^{69}$, Figure 3) [9], and alanine substitution of these residues in Sco-CHH significantly decreased its hyperglycemic activity [9] $\mathrm{Ile}^{71}$ and $\mathrm{Gly}^{73}$, respectively in $\alpha-5$ and the $C$-terminal end, are two highly conserved hydrophobic residues among CHH-L peptides (Figure 3) [9]. In addition, $\mathrm{Glu}^{45}$, located in $\pi 4$, occupies a conserved position where, among CHH-L peptides, a negatively charged residue (Glu or Asp) is present (Figure 3) [9], and two negative residues $\left(\mathrm{Glu}^{62}\right.$ and $\mathrm{Glu}^{63}$ ) located in $\alpha 5$-helix were also chosen for alanine substitution.

When tested in the $\mathrm{Na}^{+}, \mathrm{K}^{+}$-ATPase activity in gill 6, the pump-stimulating activity of six mutants (I2A, F3A, E45A, D69A, I71A, and G73A Sco-CHH-L) significantly decreased, whereas that of V41A, N60A, E62A, and E63A Sco-CHH-L did not, when compared with the wild-type Sco-CHH-L (Figure 5). The functionally important residues are in steric proximity, despite the fact that most are located at either end of the sequence (Figure 3), which is brought towards each other in the structure of Sco-CHH-L. Thus, $\mathrm{Ile}^{71}$, Gly ${ }^{73}$, $\mathrm{Glu}^{45}$, and $\mathrm{Asp}^{69}$ are on a continuous stretch of the surface, with the two $\mathrm{N}$-terminal end residues $\left(\mathrm{Ile}^{2}\right.$ or Phe ${ }^{3}$ ) being located nearby (Figure 6).
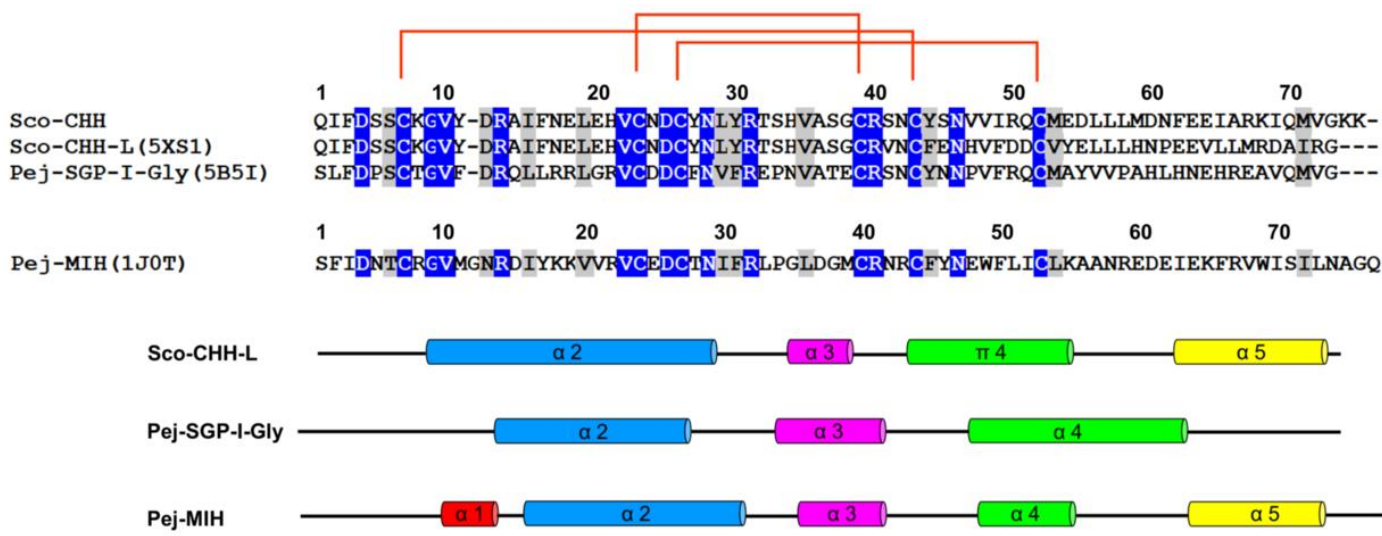

Figure 3. Sequence alignment and secondary structure of four $\mathrm{CHH} / \mathrm{ITP}$ peptides. Sequence alignment and secondary structure of four $\mathrm{CHH}$-superfamily peptides. Amino acid sequences of the mature peptide of three Type-I peptides, Sco$\mathrm{CHH}$, Sco-CHH-L, and Pej-SGP-I-Gly, and that of a Type-II peptide, Pej-MIH, are aligned. Accession number for the amino acid sequence is, respectively AY372181, EF530127, AB007507, and P55847. For Sco-CHH-L, Pej-SGP-I-Gly, and Pej-MIH, location of the secondary structures is given. The conserved pattern of disulfide bridge connectivity $\left(\mathrm{Cys}^{7}-\mathrm{Cys}^{43 / 44}\right.$, Cys $^{23 / 24}-$ Cys $^{39 / 40}$, and Cys $^{26 / 27}-$ Cys $^{52 / 53}$ ) is indicated by orange lines. 
A

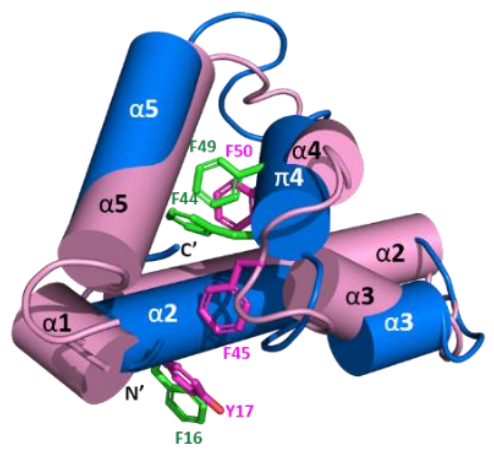

B

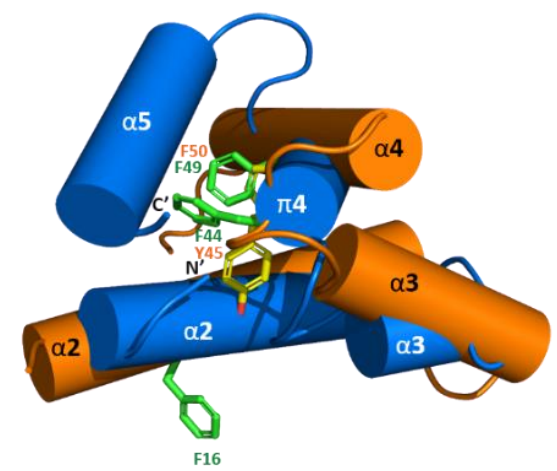

Figure 4. Superposition of Sco-CHH-L with Pej-MIH and Pej-SGP-I-Gly. Structure of Sco-CHH-L (blue) is superposed with (A) Pej-MIH (pink) and with (B) Pej-SGP-I-Gly (orange). Note that Sco-CHH-L is well aligned with Pej-MIH with the $\mathrm{N}$ - and C-terminus being brought near together, while the two termini of Pej-MIH are kept away in Pej-SGP-I-Gly. Side chains of the conserved aromatic residues in Sco-CHH-L (Phe ${ }^{16}, \mathrm{Phe}^{44}$, and $\mathrm{Phe}^{49}$ in green), MIH (Tyr ${ }^{17}$, Phe ${ }^{45}$, and Phe ${ }^{50}$ in magenta), and Pej-SGP-I-Gly (Tyr ${ }^{45}$ and $\mathrm{Phe}^{50}$ in yellow) are shown. Note the aromatic ring of $\mathrm{Phe}^{16} / \mathrm{Tyr}^{17}$ pointing away from the core structure.

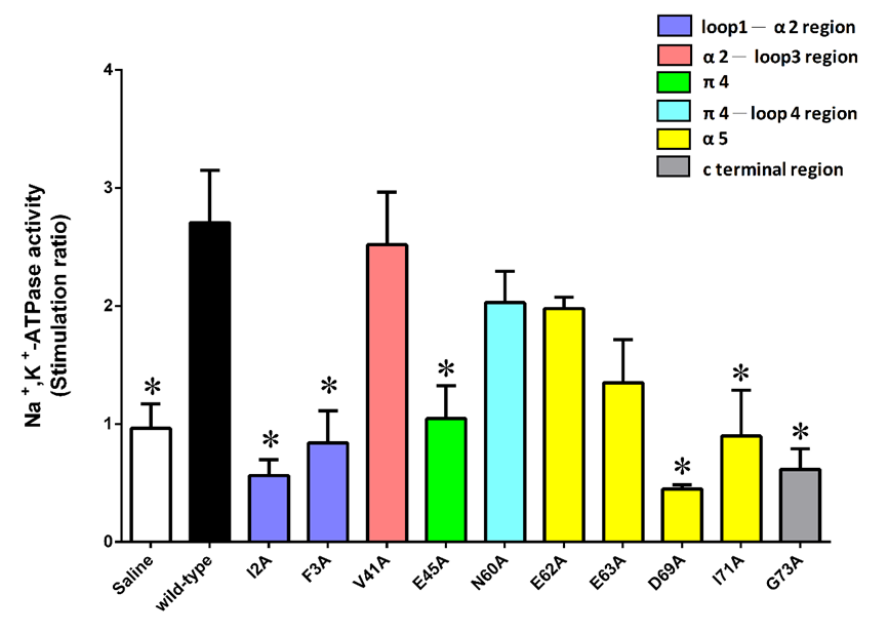

Figure 5. Determination of the functionally important residues of Sco-CHH-L for the Na+, $\mathrm{K}+-$ ATPase activity in posterior gills of the mud crab Scylla olivacea. The posterior gill (gill 6) were dissected out and received perfusion of saline, Sco-CHH-L, or an alanine-substituted Sco-CHH-L mutant at $125.0 \mathrm{pM}$ preparation. Data are means \pm SEM and expressed as stimulation ratio. $n=5$ for each point. The asterisk $\left(^{*}\right)$ indicates significantly different from the Sco-CHH-L group at $5 \%$ level.

A

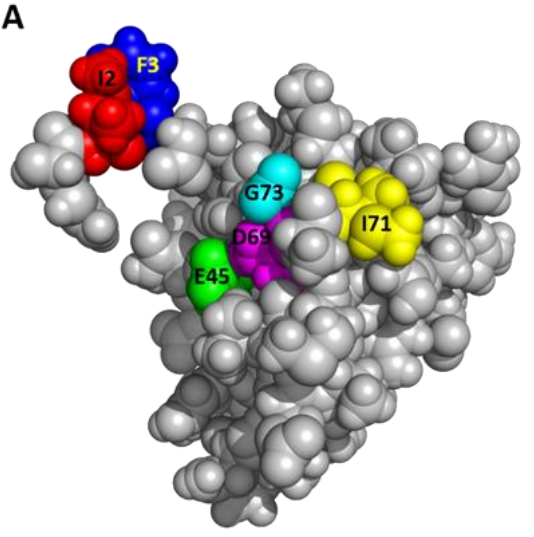

B

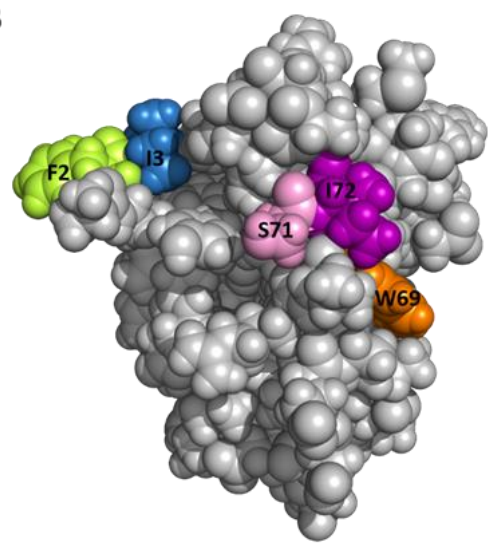

Figure 6. Close proximity of functionally important residues on the surface of the structure. The space-filling model for (A) Sco-CHH-L and (B) Pej-MIH with the residues possibly constituting receptor binding site are shown in color. 


\section{Discussion}

We demonstrated in the present study that a CHH-like peptide (Sco-CHH-L), preferentially expressed in the pericardial organs of the mud crab (Scylla olivacea) with its transcript levels being up-regulated by hypo-osmotic stresses, stimulated in vitro the $\mathrm{Na}^{+} / \mathrm{K}^{+}$-ATPase activity in the posterior gills, establishing a specific role for the peptide in osmoregulation. The solution structure of Sco-CHH-L was resolved, of which the comparison with the structure of other family members defines a molecular topology that is characteristic of the crustacean members of the $\mathrm{CHH}$-superfamily. Pump-activating activity of ten alaninesubstituted Sco-CHH-L mutants was tested in the $\mathrm{Na}^{+}, \mathrm{K}^{+}$-ATPase activity assay, showing that the functionally critical residues are present at both ends of the structure, which are sterically close to each other, presumably constituting the receptor binding/activation sites.

One interesting feature of the crustacean peptides belonging to the $\mathrm{CHH}$ superfamily is that they are often characterized as being pleiotropic in regulatory function, and, in some instances, different peptide members are both active in the same bioassay (although with different degree of potency) [11,34]. For example, $\mathrm{CHH}$ is best characterized for its role in stress-induced hyperglycemia, but has also been shown to exert inhibitory effect on ecdysteroid synthesis and secretion by the Y-organ, for which $\mathrm{MIH}$ is considered the principle regulator [35-38]. On the other hand, $\mathrm{CHH}$ and $\mathrm{CHH}-\mathrm{L}$ peptides are alternative splice forms of chh gene [11]. CHH-L peptides from several species have been shown possessing neither $\mathrm{CHH}$ (hyperglycemic) nor MIH (ecdysteroidogenesis-inhibiting) activity [22-24]. In this regard, it is noted that early studies suggested the presence of putative factor(s) in the neuroendocrine tissues, including the eyestalk X-organ/sinus gland complex and pericardial organs, which are involved in osmoregulation [28,30,39]. More recent studies have clarified to some extent the identity and molecular target of action of these factors. Thus, $\mathrm{CHH}$, specifically a CHH isoform containing a D-Phe ${ }^{3}$ residue, when in vivo injected, was able to significantly increase the eyestalk ablation-induced decrease in hemolymph osmolality, $\mathrm{Na}^{+}$concentration, or both, in the freshwater crayfish Astacus leptodactylus [40] and the American lobster Homarus americanus [41]; $\mathrm{CHH}$ purified from the crab Pachygrapsus marmoratus was able to increase in vitro trans-epithelial electrical potential difference and $\mathrm{Na}^{+}$influx in the posterior gills [42]; $\mathrm{CHH}$ derived from the freshwater crayfish Cherax quadricarinatus was effective in restoring stress-induced decrease in hemolymph $\mathrm{Na}^{+}$and $\mathrm{K}^{+}$levels to the pre-stress levels [43]. A gut-derived $\mathrm{CHH}$ in the crab Carcinus maenas was demonstrated to be involved in regulating water and ion uptake during molting, allowing the swelling necessary for successful ecdysis and the subsequent increase in size during postmolt [44]. Interestingly enough, apart from the identified $\mathrm{CHH}$, other factors of unknown identity in the sinus glands were also found to be effective in certain osmoregulatory parameters measured [41,42]. In addition, the molecular target(s) on which $\mathrm{CHH}$ acts to achieve its osmo-ionic regulation were not directly addressed by these studies, although it has been suggested that an increase in energy availability as a result of $\mathrm{CHH}$-stimulated glycogen mobilization is a probable mode of action [43], a suggestion compatible with the data showing that exposing the shore crabs $C$. maenas to dilute seawater increased the levels of glucose in the gills and hemolymph $\mathrm{CHH}$ [45]. In this regard, it is relevant to note that in the Christmas Island blue crab Discoplax celeste, two $\mathrm{CHHs}$ were found effective in stimulating $\mathrm{Na}^{+}$transport across the gill epithelia in a seasonally dependent manner, but have no effect on gill $\mathrm{Na}^{+} / \mathrm{K}^{+}$-ATPase or V-ATPase activity [46]. On the other hand, $\mathrm{Pt}-\mathrm{CHH} 2$, a CHH-L peptide of the crab Portunus trituberculatus, was suggested to be a regulator for gill $\mathrm{Na}^{+} / \mathrm{K}^{+}$-ATPase and carbonic anhydrase activity, as CHH dsRNA treatment that decreased $\mathrm{Pt}-\mathrm{CHH} 2$ transcript levels significantly reduced the enzyme activity in the gills [47].

In the present study, we showed that the transcript levels of Sco-CHH-L were increased by exposing animals to a hypo-osmotic stress ( $25 \mathrm{ppt}$ to $5 \mathrm{ppt}$ transfer), but not to a hyperosmotic stress (25 ppt to $45 \mathrm{ppt}$ transfer). Many marine decapods, including Scylla spp., actively regulate hemolymph osmolality in diluted seawater, but comply as an osmoconformer in concentrated seawater [48-50]. Thus, the Sco-CHH-L expression pattern, in 
response to osmotic challenges, suggested that $\mathrm{ScO}-\mathrm{CHH}-\mathrm{L}$ is involved in osmoregulation when S. olivace faces hypo-osmotic stresses. Corroboratively, data showing that Sco- $\mathrm{CHH}-$ $\mathrm{L}$ peptide, but not $\mathrm{ScO}-\mathrm{CHH}$, stimulated in vitro the gill $\mathrm{Na}^{+} / \mathrm{K}^{+}$-ATPase, indicated that its osmo-regulatory functions are mediated, at least in part, via stimulating the $\mathrm{Na}^{+} / \mathrm{K}^{+}$ATPase pump activity. Our data and those mentioned above collectively indicate that $\mathrm{CHH}$ and $\mathrm{CHH}-\mathrm{L}$ peptides are both important factors for regulating water and ionic balance, but these peptides likely do so via acting on distinct molecular targets, perhaps in a concerted manner.

Structure of Sco-CHH-L was compared and contrasted with those of two other CHHsuperfamily peptides, namely, Pej-MIH and Pej-SGP-I-Gly [25,26]. The six invariant cysteine residues with a unique disulfide bridge connectivity (C1-C5, C2-C4, and C3-C6, Figure 3) is a signature of the superfamily that shapes the overall fold of the peptides [11]. The common core of all three of the structures is composed of three helices, $\alpha 2$, $\alpha 3$, and $\alpha 4$ $(\pi 4$, in Sco-CHH-L), that have similar topological relationships, with $\alpha 2$ and $\alpha 3$ running in anti-parallel direction and $\alpha 4(\pi 4)$ running orthogonally (Pej-SGP-I-Gly) or obliquely (Pej-MIH and Sco-CHH-L) to $\alpha 2 / \alpha 3$ (Figure 2). Three aromatic residues in the hydrophobic core of a venom toxin (Ta1a), a venom peptide of the $\mathrm{CHH}$-superfamily, have been suggested to play a role in the packing of the structure [10]. The three aromatic residues are conserved in the Pej-MIH and Sco-CHH-L, respectively as $\mathrm{Tyr}^{17}, \mathrm{Phe}^{45}, \mathrm{Phe}^{50}$, and $\mathrm{Phe}^{16}$, Phe ${ }^{44}$, and $\mathrm{Phe}{ }^{49}$, and only the second $\left(\mathrm{Tyr}^{44}\right)$ and third $\left(\mathrm{Phe}^{49}\right)$ aromatic residues are present in SGP-I-Gly (Figure 3). It appears that for these peptides, only the second and third aromatic residues, being buried in the hydrophobic core, are involved in the packing of the structure, while the side chain of the first conserved residue (in Pej-MIH and $\mathrm{Sco}-\mathrm{CHH}-\mathrm{L}$ ) is lying on the surface of the structure (Figure 4). There are other hydrophobic residues that are conserved across the $\mathrm{CHH}$-superfamily peptides and have been suggested to stabilize the structure (Figure 3) [11,25]; among those residues, only $\mathrm{Ile}^{15}$, $\mathrm{Val}^{35}$, and $\mathrm{Val}^{53}$ are located inside the Sco-CHH-L structure and likely contribute to the stabilization of the structure.

Sco-CHH-L shares the most significant topological similarity with Pej-MIH. Besides both having $\alpha 2, \alpha 3$, and $\alpha 4$ (or $\pi 4$ ), they are the two structures that form a topologically equivalent $\alpha 5$ helix, running in an anti-parallel fashion to $\alpha 4$ (or $\pi 4$ ), with the $C$-terminal end being directed towards the $N$-terminal tail (Figures 2 and 3). Towards the $N$-terminus, Pej-MIH additionally has a short $\alpha 1$, while the relatively longer $\alpha 2$ in Sco-CHH-L encompasses the region corresponding to that of the $\alpha 1$ in Pej-MIH (Figure 3). Interestingly, one of the sequence features distinguishing Type I and Type II peptides is that the former group (e.g., CHH-L peptide) lacks a Gly ${ }^{12}$ residue, which is present in the latter (e.g., MIH) [11]. Glycine is known to be a helix breaker, prone to disrupt the regularity of $\alpha$ helical backbone conformation [51]. Thus, it is suggested that the presence or absence of the Gly ${ }^{12}$ residue is related to the distinct conformation of the Type I and II peptides in that Sco-CHH-L forms a continuous and long $\alpha 2$, and the corresponding region of Pej-MIH, having a Gly ${ }^{12}$, breaks into two helices ( $\alpha 1$ and $\alpha 2$ ), providing a topological signature that differentiates Type I and Type II peptides (Figure 3), which probably bears functionally important significance as experimental insertion of a $\mathrm{Gly}^{12}$ residue into the shrimp $\mathrm{CHH}\left(\mathrm{CHH}-\mathrm{Gly}^{12}\right)$ significantly decreased its hyperglycemic activity [4].

Superposing Sco-CHH-L on Pej-SGP-I-Gly, an M. japonicas CHH precursor, revealed a lower level of resemblance with a higher backbone RMSD. It is somewhat surprising as both structures, as mentioned above, are constrained and shaped by the same disulfide bridge connectivity. The two structures differ significantly in that Pej-SGP-I-Gly, lacking an $\alpha 5$, has a relatively long $\alpha 4$ with the $C$-terminal tail being kept away from the $N$-terminal end, while Sco-CHH-L forms, as mentioned above, an $\alpha 5$ which runs in an anti-parallel fashion against $\alpha 4$, with the $C$-terminal end being close to the $N$-terminus (Figure 2 ). It is interesting to note that HAND toxins, Ta1a and Ssm6a, characteristically lack the $C$ terminal $\alpha 5$, a structural change thought to be leading to "weaponization" of the ancestral hormonal peptides, by losing the $C$-terminus of the ancestral sequence that contained 
$\alpha 5$ [10]. Pej-SGP-I-Gly, however, has a rather long C-terminal tail following the $\alpha 4$. As $\mathrm{CHH}$ and $\mathrm{CHH}-\mathrm{L}$ peptides are alternatively spliced forms of chh gene having the same sequence up to the first 40 residues but differing significantly after the 40th residues [31], it is possible that the topological differences between Pej-SGP-I-Gly and Sco-CHH-L could be attributed to the differences in the post-40th-residue sequence (Figure 3). It should also be noted however that Pej-SGP-I-Gly is a non-amidated, glycine-extended precursor of the Pej-SGP-I CHH [26]. CHH is post-translationally amidated at the $C$-terminal end, which is required for full hyperglycemic activity and the $\alpha$-helical content of $\mathrm{CHH}$ increased after the peptide was amidated $[24,52,53]$, indicating that $C$-terminal amidation of the peptide leads to structural changes. Whether the structure of Pej-SGP-I-Gly will change, particularly at the $C$-terminus and its topological relationship with the other areas of the structure, as a result of amidation of the peptide, is an interesting issue awaits interrogation.

Effects of alanine-substituted mutant on the gill $\mathrm{Na}^{+} / \mathrm{K}^{+}$-ATPase revealed several residues that are functionally important in the Sco-CHH-L (Figure 5). Side chains of these residues are located on the surface of the structure, and these residues are located at either end of the peptide but in steric proximity (Figure 6). It is suggested that the parts of the structure, consisting of these residues, play important roles in forming the binding site for receptor interaction, a suggestion that is applicable to other members of the family, as functionally critical residues at either end of the $\mathrm{MIH}, \mathrm{CHH}$, and ITP sequences have also been experimentally demonstrated $[2,4,5,9]$. With respect to $\mathrm{MIH}$, the suggestion is additionally supported by the observation that the two ends of the Pej-MIH are, similar to those of Sco-CHH-L, sterically close to each other (Figure 2), and that the functionally critical residues of each peptide occupy topologically similar positions in the respective structure (Figure 6). It is further noted that, although the presumed binding sites of the two peptides are topologically similar, differences in the side-chain property exist. Thus, whereas both peptides have in common two hydrophobic residues, $\mathrm{Ile}^{2} / \mathrm{Phe}^{3}$ in Sco-CHH$\mathrm{L}$ and $\mathrm{Phe}^{2} / \mathrm{Ile}^{3}$ in Pej-MIH, a negatively charged residue $\left(\mathrm{Asp}^{12}\right)$ in the former peptide is replaced by an uncharged residue $\left(\mathrm{Asn}^{13}\right)$ in the latter (Figure 6). Asp ${ }^{12}$ in Sco-CHH and $\mathrm{Asn}^{13}$ in Pej-MIH have been shown to be functionally important [4,9]. Similarly, there are two negatively charged residues $\left(\mathrm{Glu}^{45}\right.$ and $\left.\mathrm{Asp}^{69}\right)$ in Sco-CHH-L that are characteristically absent in Pej-MIH (Figure 6). It is relevant to mention that receptor binding assay using radiolabeled ligands and membrane preparations derived from potential target tissues suggested the existence of separate binding sites (receptors) for distinct members of the superfamily $[54,55]$. Differences in the property of the residues presumably constituting the binding sites could contribute to the observed receptor binding specificity. Nonetheless, cross binding and activation of receptor by a non-cognate ligand is possible to certain degree due to high similarity in the overall fold of the peptides. How the functional specificity and oftentimes the functional overlap as observed for the crustacean members of the CHH-superfamily (see [56]) are achieved through interaction of peptide ligands of a common fold with their specific receptors represents an endeavor awaiting to be pursued for better understanding of functional diversification through structural changes and endocrine regulation of crustacean physiology.

\section{Materials and Methods}

\subsection{Animal Maintenance}

Adult mud crabs Scylla olivacea (carapace width: $\sim 7-8 \mathrm{~cm}$ ) were purchased from Wu-chi Fishing Port, Taichung, Taiwan, transported to the National Changhua University of Education, and acclimated in tanks containing 25 ppt artificial seawater (Blue Treasure), which was continuously aerated and circulated through a bio-filter at $24-26{ }^{\circ} \mathrm{C}$ under a $14 \mathrm{~h} / 10 \mathrm{~h}$ light/dark cycle [57].

\subsection{ELISA for the Quantitative Analysis of Sco-CHH-L and Sco-CHH in Pericardial Organs}

The pericardial organs were dissected from animals and processed for protein extraction [24]. Levels of Sco-CHH-L and Sco-CHH in the extracts were quantified using an 
enzyme-linked immunosorbent assay [24] with antibodies specifically against Sco-CHH-L or Sco-CHH [31] and purified recombinant Sco-CHH-L and Sco-CHH [24] as standards.

\subsection{Gene Expression under Osmotic Stresses}

For the experiments of osmotic stress, the animals, acclimated to $25 \mathrm{ppt}$ artificial seawater for at least 7 days, were transferred to either 5 ppt or 45 ppt salinity. Crabs were sacrificed at before $(0 \mathrm{~h}), 6 \mathrm{~h}, 12 \mathrm{~h}$, or $24 \mathrm{~h}$ after transfer for harvesting of the pericardial organs, which were frozen directly in liquid nitrogen before use. Total RNA were isolated from the pericardial organs and reversed transcribed according to previous study [58]. A protocol for a semi-quantitative real-time PCR was adopted to quantify Sco-CHH and Sco-CHH-L transcript levels. Primer sequences for amplification of 18s rRNA (reference), $\mathrm{Sco}-\mathrm{CHH}$, and Sco-CHH-L (targets) genes were listed in Table S2. The real-time PCR amplifications were performed as follows: $95^{\circ} \mathrm{C}$ for $10 \mathrm{~min}$, followed by 40 cycles of $95^{\circ} \mathrm{C}$ for $10 \mathrm{~s}, 60^{\circ} \mathrm{C}$ for $7 \mathrm{~s}$, and $72{ }^{\circ} \mathrm{C}$ for $7 \mathrm{~s}$. Amplification specificity and efficiency of each pair of primers were experimentally validated according to previous study [52]. The comparative threshold cycle method was used to determine transcript levels of the target genes. Thus, levels of Sco-CHH and Sco-CHH-L gene expressions were normalized to those of $18 \mathrm{~s}$ rRNA gene concurrently amplified. Normalized levels of the target genes at each time point were expressed relative to those at zero hour (arbitrarily designated as the calibrator).

\subsection{Construction of Expression Plasmids and Production of Recombinant Peptides}

Production, amidation, and characterization of the wild-type recombinant Sco-CHH and Sco-CHH-L have been previously described [24]. In addition, construction of the recombinant plasmids, each expressing an alanine-substituted mutant of Sco-CHH-L (I2A, F3A, V41A, E45A, N60A, E62A, E63A, D69A, I71A, and G73A Sco-CHH-L), was performed using the QuikChange PCR-mediated Site-Directed Mutagenesis Kit (Agilent) according to the manufacturer's instruction with the plasmid pET-22b(+)-Sco-CHH-L encoding the wild-type Sco-CHH-L [24] as polymerase chain reaction (PCR) template. The synthetic oligonucleotides used in the PCR reactions were listed in Table S2. Each constructed plasmid was sequenced (Mission Biotechnology Inc., Taipei, Taiwan) to ensure the intended sequence was constructed.

Production of recombinant peptides was performed essentially as described in previous report with modifications [24]. Briefly, Escherichia coli BL21(DE3) competent cells $\left(\right.$ Novagen $^{\circledR}$ ) transformed with each of the plasmids (I2A, F3A, V41A, E45A, N60A, E62A, E63A, D69A, I71A, and G73A pET-22b(+)-Sco-CHH-L) encoding an alanine-substituted Sco-CHH-L. For production of peptides to be used for testing their effects on $\mathrm{Na}^{+}, \mathrm{K}^{+}-$ ATPase activity, transformed cells were grown in Luria-Bertani (LB) medium containing ampicillin $(100 \mu \mathrm{g} / \mathrm{mL})$ at $37^{\circ} \mathrm{C}$, and the expression was induced with isopropyl $\beta$-D-1thiogalactopyranoside (IPTG) at $1 \mathrm{mM}$ at $37^{\circ} \mathrm{C}$ for $4 \mathrm{~h}$. For isotope labeling, cells transformed with pET-22b(+)-Sco-CHH-L were grown in M9 minimal medium with ${ }^{15} \mathrm{NH}_{4} \mathrm{Cl}$ $(1 \mathrm{~g} / \mathrm{L})$ as the nitrogen source and ${ }^{13} \mathrm{C}$-glucose $(2 \mathrm{~g} / \mathrm{L})$ as the carbon source. Expression of labeled peptides was induced with $0.5 \mathrm{mM} \mathrm{IPTG}$ at $25{ }^{\circ} \mathrm{C}$ for $12 \mathrm{~h}$.

After IPTG induction, cells were harvested by centrifugation $\left(6000 \times g, 20 \mathrm{~min}, 4^{\circ} \mathrm{C}\right)$, suspended in $10 \mathrm{mM}$ phosphate buffered saline (PBS, pH 7.4), and lysed using a highpressure homogenizer (GW technologies, Taiwan). After centrifugation $(30,000 \times g, 30 \mathrm{~min}$, $4{ }^{\circ} \mathrm{C}$ ), both supernatants and pellets were analyzed using $16.5 \%$ Tricine-Sodium Dodecyl Sulphate-Polyacrylamide Gel Electrophoresis (Tricine-SDS-PAGE) [57], which showed most expressed proteins were in the pellets.

A refolding protocol [24] with modification was used to refold the recombinant peptides in the pellets. Briefly, the pellets were first denatured in $100 \mathrm{mM}$ Tris- $\mathrm{HCl}$, at $\mathrm{pH}$ 8.0, containing $6 \mathrm{M}$ guanidine- $\mathrm{HCl}$ and the reactions incubated at $4{ }^{\circ} \mathrm{C}$ overnight $(12 \mathrm{~h} \sim 16 \mathrm{~h})$ with stirring. After centrifugation $\left(30,000 \times g, 30 \mathrm{~min}, 4^{\circ} \mathrm{C}\right)$, the supernatant was applied to a $\mathrm{C}_{18}$ Sep-Pak ${ }^{\circledR}$ cartridge (WAT043345, Waters) and eluted with $60 \%$ acetonitrile. The col- 
lected fractions were lyophilized, and the lyophilized samples dissolved in $250 \mathrm{mM}$ Tris-base buffer with $8 \mathrm{M}$ Urea at $\mathrm{pH} 8.5(1: 100 \mathrm{w} / \mathrm{v})$. Subsequently, the dissolved samples were slowly diluted with 19 volumes of a refolding buffer containing $250 \mathrm{mM}$ Tris-base, $10 \%$ glycerol, $5 \mathrm{mM}$ cysteine, $0.5 \mathrm{mM}$ cystine, $\mathrm{pH} 8.3$, after which urea was added to the refolding reaction to a final concentration of $1.5 \mathrm{M}$. The refolding reaction was incubated at $4{ }^{\circ} \mathrm{C}$ for $20 \mathrm{~h}$ with stirring $(300 \mathrm{rpm})$. Subsequently, the refolding reaction was filtered through a PES membrane $(0.22 \mu \mathrm{m})$ and the filtrate concentrated using an ultrafiltration apparatus with a 5 kDa molecular mass cut-off (Vivaflow ${ }^{\circledR} 200$ cassette, Sartorius Stedim Biotech, Göttingen, Germany). The concentrate was separated by reversed phase (RP-HPLC) system with water/acetonitrile gradient to obtain purified recombinant peptides [24].

Mass and purity of the purified recombinant peptides were determined using Micro Mass Quattro Ultima mass spectrometer with the electron spray ionization (ESI-MASS). Concentration of the recombinant peptides was determined using Pierce BCA Protein Assay Kit (Thermo Fisher Scientific, Waltham, MA, USA) with bovine serum albumin as the standard.

\subsection{Circular Dichroism Spectral Analysis of Recombinant Wild-Type and Alanine-Substituted Sco-CHH-L}

Far-ultraviolet circular dichroism (Far UV CD) spectra of the recombinant peptides that were used in the gill $\mathrm{Na}^{+}, \mathrm{K}^{+}$-ATPase activity assay were measured by an Aviv CD spectrometer (Model 202, Aviv Biomedical Inc., Lakewood, NJ, USA) in phosphate buffered saline with $15 \mu \mathrm{M}$ of peptides. An aliquot $(300 \mu \mathrm{L})$ of the samples was placed in a 1-mm cell path length quartz cell and each spectrum, an average of three scans, was collected at $25^{\circ} \mathrm{C}$ with a wavelength range of 260 to $200 \mathrm{~nm}$ in $0.5 \mathrm{~nm}$ increments. Raw data were baseline corrected, smoothed, and transformed to obtain spectra in units of mean residue ellipticity according to Zhou et al. (1994) [59]. The ellipticity at $222 \mathrm{~nm}$ was used to estimate the $\alpha$-helical content of the peptides using DichroWeb sever [60].

\subsection{Effects of Wild-Type Peptides and Mutated Sco-CHH-L Peptides on $\mathrm{Na}^{+}, \mathrm{K}^{+}$-ATPase Activity}

To establish a dose-dependent curve for the effect of Sco-CHH-L and Sco-CHH on the $\mathrm{Na}^{+}, \mathrm{K}^{+}$-ATPase activity in the 6th pair of gills (gill 6), the enzyme-specific activity was determined using an assay previously developed for S. paramamosain [61] with some modifications. After being acclimated for 7 days in 25 ppt seawater, crabs were sacrificed on ice and the 6th pair of gills were removed from the branchial chambers. Hemolymph of the tissues was flushed out using excessive volume of Pantin's saline injected through the cut end of the efferent and afferent vessels using a hypodermic syringe with a 25-G needle. Subsequently, one of the pairs of gills was perfused with Pantin's saline, while the contralateral one was perfused with saline containing the desired dose of wild-type Sco-CHH-L or Sco-CHH. Preliminary tests indicated that there was no significant difference in basal enzyme activity between the left and right gills (left: $19.09 \pm 3.38 \mu \mathrm{mole} \mathrm{Pi} / \mathrm{mg}$ protein $/ \mathrm{h}$; right: $19.59 \pm 2.34 \mu$ mole $\mathrm{Pi} / \mathrm{mg}$ protein $/ \mathrm{h}, n=3$ for each group), hence, gills were randomly assigned to the saline-treated or peptide-treated groups. Tissues were then individually incubated at $25^{\circ} \mathrm{C}$ for $30 \mathrm{~min}$ in culture dish with saline or saline containing the recombinant peptides at the same dose that was used to perfuse the tissues. After incubation, each gill was cut into small pieces and homogenized in $500 \mu \mathrm{L}$ of homogenization buffer ( $25 \mathrm{mM}$ Tris- $\mathrm{HCl}, 250 \mathrm{mM}$ sucrose, $20 \mathrm{mM}$ EDTA, $0.4 \%$ sodium deoxycholate, $\mathrm{pH} 7.4$ ) containing protease inhibitors (in final concentration $16.5 \mu \mathrm{M}$ antipain, $10.8 \mu \mathrm{M}$ leupeptin, $320 \mu \mathrm{M}$ benzamidine, and $50 \mu \mathrm{M}$ aprotinin, Sigma) using an ultrasonic processor. Crude homogenates were centrifuged $\left(6000 \times g, 4{ }^{\circ} \mathrm{C}, 15 \mathrm{~min}\right)$ and the resulting supernatants re-centrifuged $\left(30,000 \times \mathrm{g}, 4^{\circ} \mathrm{C}, 20 \mathrm{~min}\right)$. An aliquot of the final supernatants was saved for determination for total protein by Bio-Rad Protein Assay Kit (\#5000002, Bio-Rad, Hercules, CA, USA) with bovine serum albumin as the standard at $595 \mathrm{~nm}$, and the rest of the supernatants immediately used for determination of $\mathrm{Na}^{+}, \mathrm{K}^{+}$-ATPase activity assay.

The protocol for $\mathrm{Na}^{+}, \mathrm{K}^{+}$-ATPase activity has been described by Chung and Lin [61]. The $\mathrm{Na}^{+}, \mathrm{K}^{+}$-ATPase activity was assayed by adding $10 \mu \mathrm{L}$ of the supernatant to $0.4 \mathrm{~mL}$ of 
reaction buffer, which was, for the ouabain-free group, $20 \mathrm{mM}$ imidazole, $100 \mathrm{mM} \mathrm{NaCl}$, $30 \mathrm{mM} \mathrm{KCl}$, and $10 \mathrm{mM} \mathrm{MgCl} 2$ at $\mathrm{pH} 7.4$, or for the ouabain group, $20 \mathrm{mM}$ imidazole, $130 \mathrm{mM} \mathrm{NaCl}, 10 \mathrm{mM} \mathrm{MgCl}_{2}$, and $1 \mathrm{mM}$ ouabain at $\mathrm{pH}$ 7.4. Reaction was initiated by adding $0.1 \mathrm{~mL}$ of the ATP stock solution ( $\left.25 \mathrm{mM} \mathrm{Na}_{2} \mathrm{ATP}\right)$, incubated for $15 \mathrm{~min}$ at $30^{\circ} \mathrm{C}$, quenched by adding $0.2 \mathrm{~mL}$ of an ice-cold trichloroacetic acid solution $(30 \% w / v)$, and centrifuged $\left(1640 \times g, 4{ }^{\circ} \mathrm{C}, 10 \mathrm{~min}\right)$. An aliquot $(0.5 \mathrm{~mL})$ of the supernatants was taken and subsequently reacted with $1 \mathrm{~mL}$ ice-cold Bonting's colorimetric solution $(176 \mathrm{mM}$ $\mathrm{FeSO}_{4}, 560 \mathrm{mM} \mathrm{H}_{2} \mathrm{SO}_{4}, 8.1 \mathrm{mM}$ ammonium molybdate) at $20{ }^{\circ} \mathrm{C}$ water bath for $20 \mathrm{~min}$. Concentration of the inorganic phosphate $(\mathrm{Pi})$ was measured spectrophotometrically at $700 \mathrm{~nm}$ (Hitachi, Tokyo, Japan) according to Peterson's method [62]. The $\mathrm{Na}^{+}, \mathrm{K}^{+}$-ATPase activity was calculated as the difference in the levels of Pi between the ouabain group and the ouabain-free group, and normalized by tissue total proteins $[61,63,64]$.

The effect of peptides on $\mathrm{Na}^{+}, \mathrm{K}^{+}$-ATPase activity was calculated and expressed as the stimulation ratio, i.e., the activity of the peptide-treated gill over the enzyme-specific activity of the contralateral saline-treated gill.

To test the effect of rSco-CHH-L mutants on the $\mathrm{Na}^{+}, \mathrm{K}^{+}$-ATPase activity, the pairs of gills were dissected, treated, and incubated with saline, wild-type Sco-CHH-L, or each of the Sco-CHH-L mutants (peptide concentration at $125 \mathrm{pM}$ ), processed for determination of the enzyme-specific activity, and calculated for the stimulation ratio as described above.

\subsection{Nuclear Magnetic Resonance Spectroscopy and Structure Determination}

${ }^{13} \mathrm{C} /{ }^{15} \mathrm{~N}$-labelled recombinant Sco-CHH-L $(0.9 \mathrm{mM})$ was buffered in citric acid-sodium phosphate buffer $(10 \mathrm{mM}$ citric acid-sodium phosphate, $100 \mathrm{mM} \mathrm{NaCl}, 10 \mathrm{mM}$ potassium chloride, $50 \mathrm{mM}$ L-glutamate, $\mathrm{pH}$ 3.0) containing $10 \%(v / v) \mathrm{D}_{2} \mathrm{O}$. 4,4-dimethyl-4 silapentane-1 sulfonic acid (DSS) was then added as internal reference. NMR spectra were acquired on Bruker Avance $600 \mathrm{MHz}, 850 \mathrm{MHz}$, and Varian $700 \mathrm{MHz}$ spectrometer at $25^{\circ} \mathrm{C}$. Heteronuclear single quantum coherence (HSQC) spectroscopy analysis of the dissolved peptides indicated that HSQC cross peaks were well dispersed (Figure S5). Backbone assignment was accomplished with $\mathrm{HNCA}, \mathrm{HN}(\mathrm{CO}) \mathrm{CA}, \mathrm{HNCACB}, \mathrm{CBCA}(\mathrm{CO}) \mathrm{NH}$, $\mathrm{HNCO}$, and $\mathrm{HN}(\mathrm{CA}) \mathrm{CO}$ experiments. The chemical-shift resonance assignments of remaining atoms were accomplished using both ${ }^{1} \mathrm{H}-{ }^{15} \mathrm{~N}$ HSQC-NOESY with the assistance of through-bond correlation spectra. To obtain side chain resonances, combined information from $3 \mathrm{D}^{1} \mathrm{H}_{-}{ }^{15} \mathrm{~N}$ HSQC-TOCSY, HBHA(CO)NH, H(CC)(CO)NH, CC(CO)NH, HCCHCOSY, and HCCH-TOCSY spectra were analyzed. The NMR spectra were processed with Varian Vnmrj or NMRpipe, and the resonance assignments for the set of spectra were analyzed using SPARKY v3.114 [65]. The assigned resonances were deposited into the Biological Magnetic Resonance Bank (BMRB) under the entry number BMRB36099.

Structural calculations were carried out with the standard simulated annealing protocol using the CNS program [66]. Several rounds of calculations were used to eliminate the ambiguity in the assignment. The 10 lowest energy structures selected out of 200 calculated structures were then refined by the explicit water model using the GROMOS force fields [67]. The final structures were evaluated with PROCHECK-nmr software [68]. The coordinates of the ensemble of structures have been deposited into the Protein Data Bank (PDB) as entry 5XS1.

\subsection{Data and Statistical Analysis}

Data are expressed as mean values \pm S.E.M. Student's $t$-test or one-way ANOVA (with post hoc Tukey's pairwise comparison) were employed for statistical analysis (SigmaStat v. 3.5).

Supplementary Materials: Supplementary materials can be found at https:/ /www.mdpi.com/ article/10.3390/ijms222011142/s1, Figure S1: Preferential expression of Sco-CHH-L in the pericardial organs of the mud crab Scylla olivacea, Figure S2: Pattern of changes in Sco-CHH and Sco-CHH-L transcript levels in the pericardial organ of the mud crab Scylla olivacea in response to osmotic stresses, Figure S3: Far-UV circular dichroism spectra of the wild-type rSco-CHH-L and ala-nine-substituted mutants, Figure S4: NMR data confirming disulfide bridge connectivity, Figure S5: Assignment 
of amide resonances of Sco-CHH-L on a 1H-15N HSQC spectrum, Table S1: NMR restraints and structural statistics for crustacean hyperglycemic hormone-like peptide (Sco-CHH-L) from Scylla olivacea in solution, Table S2: Synthetic oligonucleotides used in this study.

Author Contributions: Conceptualization, Y.-R.C., C.-Y.L., N.-W.H. and P.-C.L.; investigation, Y.-R.C., S.-S.H. and C.-C.C.; validation, Y.-R.C. and Y.-Z.L.; writing-original draft, Y.-R.C. and C.-Y.L.; writing-review and editing, C.-Y.L., N.-W.H. and P.-C.L.; resource, J.-R.T., H.-C.L. and J.-Y.T.; supervision, C.-Y.L. and P.-C.L.; and funding acquisition, C.-Y.L. and P.-C.L. All authors have read and agreed to the published version of the manuscript.

Funding: This research was funded by the Ministry of Science and Technology (MOST), Taiwan (109-2311-B-007-004-MY3 to P.-C.L.; 108-2311-B-018-001 and 109-2311-B-018-001 to C.-Y.L.).

Institutional Review Board Statement: Experimental protocols involving animals employed by the present study were approved by the Review Committee of National Changhua University of Education (Permit number: NCUE-097123101), in full accordance with the recommendations (Guidelines for Management and Use of Experimental Animals) set by the Council of Agriculture, Taiwan.

Informed Consent Statement: Not applicable.

Data Availability Statement: The coordinates of the ensemble of structures have been deposited into the Protein Data Bank (PDB) as entry 5XS1.

Acknowledgments: The authors thank the NMR Instrumentation Center at National Tsing Hua University, Hsinchu, and Academia Sinica High-Field NMR Center (HFNMRC) for technical support. HFNMRC is funded by Academia Sinica Core Facility and Innovative Instrument Project (AS-CFII-108-112).

Conflicts of Interest: The authors declare that they have no conflict of interest with the contents of this article.

\section{References}

1. Lacombe, C.; Greve, P.; Martin, G. Overview on the sub-grouping of the crustacean hyperglycemic hormone family. Neuropeptides 1999, 33, 71-80. [CrossRef]

2. Wang, Y.J.; Zhao, Y.; Meredith, J.; Phillips, J.E.; Theilmann, D.A.; Brock, H.W. Mutational analysis of the C-terminus in ion transport peptide (ITP) expressed in Drosophila Kc1 cells. Arch. Insect Biochem. Physiol. 2000, 45, 129-138. [CrossRef]

3. Chan, S.M.; Gu, P.L.; Chu, K.H.; Tobe, S.S. Crustacean neuropeptide genes of the CHH/MIH/GIH family: Implications from molecular studies. Gen. Comp. Endocrinol. 2003, 134, 214-219. [CrossRef]

4. Katayama, H.; Ohira, T.; Nagata, S.; Nagasawa, H. Structure-activity relationship of crustacean molt-inhibiting hormone from the kuruma prawn Marsupenaeus japonicus. Biochemistry 2004, 43, 9629-9635. [CrossRef] [PubMed]

5. Zhao, Y.; Meredith, J.; Brock, H.W.; Phillips, J.E. Mutational analysis of the N-terminus in Schistocerca gregaria ion-transport peptide expressed in Drosophila Kc1 cells. Arch. Insect Biochem. Physiol. 2005, 58, 27-38. [CrossRef] [PubMed]

6. Padhi, A.; Verghese, B.; Otta, S.K.; Varghese, B.; Ramu, K. Positive Darwinian selection on crustacean hyperglycemic hormone $(\mathrm{CHH})$ of the green shore crab, Carcinus maenas. In Silico Biol. 2007, 7, 355-367. [PubMed]

7. Montagné, N.; Desdevises, Y.; Soyez, D.; Toullec, J.-Y. Molecular evolution of the crustacean hyperglycemic hormone family in ecdysozoans. BMC Evol. Biol. 2010, 10, 62. [CrossRef]

8. McCowan, C.; Garb, J.E. Recruitment and diversification of an ecdysozoan family of neuropeptide hormones for black widow spider venom expression. Gene 2014, 536, 366-375. [CrossRef] [PubMed]

9. Liu, C.J.; Huang, S.S.; Toullec, J.Y.; Chang, C.Y.; Chen, Y.R.; Huang, W.S.; Lee, C.Y. Functional Assessment of Residues in the Amino- and Carboxyl-Termini of Crustacean Hyperglycemic Hormone (CHH) in the Mud Crab Scylla olivacea Using Point-Mutated Peptides. PLoS ONE 2015, 10, e0134983. [CrossRef]

10. Undheim, E.A.; Grimm, L.L.; Low, C.F.; Morgenstern, D.; Herzig, V.; Zobel-Thropp, P.; Pineda, S.S.; Habib, R.; Dziemborowicz, S.; Fry, B.G.; et al. Weaponization of a Hormone: Convergent Recruitment of Hyperglycemic Hormone into the Venom of Arthropod Predators. Structure 2015, 23, 1283-1292. [CrossRef]

11. Webster, S.G.; Keller, R.; Dircksen, H. The CHH-superfamily of multifunctional peptide hormones controlling crustacean metabolism, osmoregulation, moulting, and reproduction. Gen. Comp. Endocrinol. 2012, 175, 217-233. [CrossRef] [PubMed]

12. Kleinholz, L.H. Crustacean Neurosecretory Hormones and Physiological Specificity. Am. Zool. 1976, 16, 151-166. [CrossRef]

13. Kegel, G.; Reichwein, B.; Tensen, C.P.; Keller, R. Amino acid sequence of crustacean hyperglycemic hormone (CHH) from the crayfish, Orconectes limosus: Emergence of a novel neuropeptide family. Peptides 1991, 12, 909-913. [CrossRef]

14. Keller, R. Crustacean neuropeptides: Structures, functions and comparative aspects. Experientia 1992, 48, 439-448. [CrossRef]

15. Soyez, D. Occurrence and diversity of neuropeptides from the crustacean hyperglycemic hormone family in arthropods. A short review. Ann. N. Y. Acad. Sci. 1997, 814, 319-323. [CrossRef] 
16. Meredith, J.; Ring, M.; Macins, A.; Marschall, J.; Cheng, N.N.; Theilmann, D.; Brock, H.W.; Phillips, J.E. Locust ion transport peptide (ITP): Primary structure, cDNA and expression in a baculovirus system. J. Exp. Biol. 1996, 199, 1053-1061. [CrossRef]

17. Christie, A.E. Neuropeptide discovery in Ixodoidea: An in silico investigation using publicly accessible expressed sequence tags. Gen. Comp. Endocrinol. 2008, 157, 174-185. [CrossRef]

18. Christie, A.E.; Nolan, D.H.; Garcia, Z.A.; McCoole, M.D.; Harmon, S.M.; Congdon-Jones, B.; Ohno, P.; Hartline, N.; Congdon, C.B.; Baer, K.N.; et al. Bioinformatic prediction of arthropod/nematode-like peptides in non-arthropod, non-nematode members of the Ecdysozoa. Gen. Comp. Endocrinol. 2011, 170, 480-486. [CrossRef]

19. Santos, E.A.; Keller, R. Crustacean hyperglycemic hormone $(\mathrm{CHH})$ and the regulation of carbohydrate metabolism: Current perspectives. Comp. Biochem. Physiol. Part A Physiol. 1993, 106, 405-411. [CrossRef]

20. Li, W.; Chiu, K.H.; Tien, Y.C.; Tsai, S.F.; Shih, L.J.; Lee, C.H.; Toullec, J.Y.; Lee, C.Y. Differential effects of silencing crustacean hyperglycemic hormone gene expression on the metabolic profiles of the muscle and hepatopancreas in the crayfish Procambarus clarkii. PLoS ONE 2017, 12, e0172557. [CrossRef]

21. Li, W.; Chiu, K.H.; Lee, C.Y. Regulation of amino acid and nucleotide metabolism by crustacean hyperglycemic hormone in the muscle and hepatopancreas of the crayfish Procambarus clarkia. PLoS ONE 2019, 14, e0221745. [CrossRef] [PubMed]

22. Dircksen, H.; Bocking, D.; Heyn, U.; Mandel, C.; Chung, J.S.; Baggerman, G.; Verhaert, P.; Daufeldt, S.; Plosch, T.; Jaros, P.P.; et al. Crustacean hyperglycaemic hormone (CHH)-like peptides and $\mathrm{CHH}$-precursor-related peptides from pericardial organ neurosecretory cells in the shore crab, Carcinus maenas, are putatively spliced and modified products of multiple genes. Biochem. J. 2001, 356, 159-170. [CrossRef]

23. Ohira, T.; Tsutsui, N.; Nagasawa, H.; Wilder, M.N. Preparation of two recombinant crustacean hyperglycemic hormones from the giant freshwater prawn, Macrobrachium rosenbergii, and their hyperglycemic activities. Zool. Sci. 2006, 23, 383-391. [CrossRef]

24. Chang, C.C.; Tsai, K.W.; Hsiao, N.W.; Chang, C.Y.; Lin, C.L.; Watson, R.D.; Lee, C.Y. Structural and functional comparisons and production of recombinant crustacean hyperglycemic hormone $(\mathrm{CHH})$ and $\mathrm{CHH}$-like peptides from the mud crab Scylla olivacea. Gen. Comp. Endocrinol. 2010, 167, 68-76. [CrossRef] [PubMed]

25. Katayama, H.; Nagata, K.; Ohira, T.; Yumoto, F.; Tanokura, M.; Nagasawa, H. The solution structure of molt-inhibiting hormone from the Kuruma prawn Marsupenaeus japonicus. J. Biol. Chem. 2003, 278, 9620-9623. [CrossRef]

26. Tsutsui, N.; Sakamoto, T.; Arisaka, F.; Tanokura, M.; Nagasawa, H.; Nagata, K. Crystal structure of a crustacean hyperglycemic hormone $(\mathrm{CHH})$ precursor suggests structural variety in the C-terminal regions of CHH superfamily members. FEBS J. 2016, 283, 4325-4339. [CrossRef] [PubMed]

27. Carlisle, D.B.; Knowles, F.G.W. Neurohæmal Organs in Crustaceans. Nature 1953, 172, 404-405. [CrossRef]

28. Cooke, I.M.; Sullivan, R.E. Hormones and neurosecretion. In The Biology of Crustacea; Atwood, H.L., Sandeman, D.C., Eds.; Academic Press: New York, NY, USA, 1982; Volume 3.

29. Christie, A.E.; Skiebe, P.; Marder, E. Matrix of neuromodulators in neurosecretory structures of the crab Cancer borealis. J. Exp. Biol. 1995, 198, 2431-2439. [CrossRef]

30. Kamemoto, F.I. Neuroendocrinology of Osmoregulation in Decapod Crustacea. Am. Zool. 1976, 16, 141-150. [CrossRef]

31. Tsai, K.W.; Chang, S.J.; Wu, H.J.; Shih, H.Y.; Chen, C.H.; Lee, C.Y. Molecular cloning and differential expression pattern of two structural variants of the crustacean hyperglycemic hormone family from the mud crab Scylla olivacea. Gen. Comp. Endocrinol. 2008, 159, 16-25. [CrossRef]

32. Aurora, R.; Srinivasan, R.; Rose, G.D. Rules for alpha-helix termination by glycine. Science 1994, 264, 1126-1130. [CrossRef] [PubMed]

33. Guex, N.; Peitsch, M.C. SWISS-MODEL and the Swiss-PdbViewer: An environment for comparative protein modeling. Electrophoresis 1997, 18, 2714-2723. [CrossRef] [PubMed]

34. Lee, C.-Y.; Tsai, K.-W.; Tsai, W.-S.; Jiang, J.-Y.; Chen, Y.-J. Crustacean hyperglycemic hormone: Structural variants, physiological function, and cellular mechanism of action. J. Mar. Sci. Technol. 2014, 22, 75-81. [CrossRef]

35. Yasuda, A.; Yasuda, Y.; Fujita, T.; Naya, Y. Characterization of crustacean hyperglycemic hormone from the crayfish (Procambarus clarkii): Multiplicity of molecular forms by stereoinversion and diverse functions. Gen. Comp. Endocrinol. 1994, 95, 387-398. [CrossRef]

36. Chung, J.S.; Webster, S.G. Moult cycle-related changes in biological activity of moult-inhibiting hormone (MIH) and crustacean hyperglycaemic hormone $(\mathrm{CHH})$ in the crab, Carcinus maenas. From target to transcript. Eur. J. Biochem. 2003, 270, 3280-3288. [CrossRef]

37. Chang, E.S.; Prestwich, G.D.; Bruce, M.J. Amino acid sequence of a peptide with both molt-inhibiting and hyperglycemic activities in the lobster, Homarus americanus. Biochem. Biophys. Res. Commun. 1990, 171, 818-826. [CrossRef]

38. Sefiani, M.; Le Caer, J.P.; Soyez, D. Characterization of hyperglycemic and molt-inhibiting activity from sinus glands of the penaeid shrimp Penaeus vannamei. Gen. Comp. Endocrinol. 1996, 103, 41-53. [CrossRef]

39. Sommer, M.J.; Mantel, L.H. Effect of dopamine, cyclic AMP, and pericardial organs on sodium uptake and Na/K-ATPase activity in gills of the green crab Carcinus maenas (L). J. Exp. Zool. Part A Ecol. Genet. Physiol. 1988, 248, 272-277. [CrossRef]

40. Serrano, L.; Blanvillain, G.; Soyez, D.; Charmantier, G.; Grousset, E.; Aujoulat, F.; Spanings-Pierrot, C. Putative involvement of crustacean hyperglycemic hormone isoforms in the neuroendocrine mediation of osmoregulation in the crayfish Astacus leptodactylus. J. Exp. Biol. 2003, 206, 979-988. [CrossRef] 
41. Charmantier-Daures, M.; Charmantier, G.; Janssen, K.P.; Aiken, D.E.; van Herp, F. Involvement of eyestalk factors in the neuroendocrine control of osmoregulation in adult American lobster Homarus americanus. Gen. Comp. Endocrinol. 1994, 94, 281-293. [CrossRef]

42. Spanings-Pierrot, C.; Soyez, D.; Van Herp, F.; Gompel, M.; Skaret, G.; Grousset, E.; Charmantier, G. Involvement of crustacean hyperglycemic hormone in the control of gill ion transport in the crab Pachygrapsus marmoratus. Gen. Comp. Endocrinol. 2000, 119, 340-350. [CrossRef] [PubMed]

43. Prymaczok, N.C.; Pasqualino, V.M.; Viau, V.E.; Rodriguez, E.M.; Medesani, D.A. Involvement of the crustacean hyperglycemic hormone $(\mathrm{CHH})$ in the physiological compensation of the freshwater crayfish Cherax quadricarinatus to low temperature and high salinity stress. J. Comp. Physiol. B Biochem. Syst. Environ. Physiol. 2016, 186, 181-191. [CrossRef] [PubMed]

44. Chung, J.S.; Dircksen, H.; Webster, S.G. A remarkable, precisely timed release of hyperglycemic hormone from endocrine cells in the gut is associated with ecdysis in the crab Carcinus maenas. Proc. Natl. Acad. Sci. USA 1999, 96, 13103-13107. [CrossRef]

45. Chung, J.S.; Webster, S.G. Binding sites of crustacean hyperglycemic hormone and its second messengers on gills and hindgut of the green shore crab, Carcinus maenas: A possible osmoregulatory role. Gen. Comp. Endocrinol. 2006, 147, 206-213. [CrossRef] [PubMed]

46. Turner, L.M.; Webster, S.G.; Morris, S. Roles of crustacean hyperglycaemic hormone in ionic and metabolic homeostasis in the Christmas Island blue crab, Discoplax celeste. J. Exp. Biol. 2013, 216, 1191-1201. [CrossRef]

47. Sun, D.; Lv, J.; Gao, B.; Liu, P.; Li, J. Crustacean hyperglycemic hormone of Portunus trituberculatus: Evidence of alternative splicing and potential roles in osmoregulation. Cell Stress Chaperones 2019, 24, 517-525. [CrossRef] [PubMed]

48. Mantel, L.H.; Farmer, L.L. Osmotic and ionic regulation. Intern. Anat. Physiol. Regul. 1983, 5, 53-161.

49. Davenport, J.; Wong, T. Responses of adult mud crabs (Scylla serrata) (Forskal) to salinity and low oxygen tension. Comp. Biochem. Physiol. Part A Physiol. 1987, 86, 43-47. [CrossRef]

50. Chen, J.-C.; Chia, P.-G. Osmotic and ionic concentrations of Scylla serrata (Forskål) subjected to different salinity levels. Comp. Biochem. Physiol. Part A Physiol. 1997, 117, 239-244. [CrossRef]

51. Chou, P.Y. Prediction of the secondary structure of proteins from their amino acid sequence. Adv. Enzymol. Relat. Areas Mol. Biol. 1978, 47, 45-148.

52. Katayama, H.; Ohira, T.; Aida, K.; Nagasawa, H. Significance of a carboxyl-terminal amide moiety in the folding and biological activity of crustacean hyperglycemic hormone. Peptides 2002, 23, 1537-1546. [CrossRef]

53. Mosco, A.; Edomi, P.; Guarnaccia, C.; Lorenzon, S.; Pongor, S.; Ferrero, E.A.; Giulianini, P.G. Functional aspects of cHH C-terminal amidation in crayfish species. Regul. Pept. 2008, 147, 88-95. [CrossRef]

54. Webster, S. High-affinity binding of putative moult-inhibiting hormone (MIH) and crustacean hyperglycaemic hormone (CHH) to membrane-bound receptors on the Y-organ of the shore crab Carcinus maenus. Proc. R. Soc. London Ser. B Biol. Sci. 1993, 251, 53-59.

55. Katayama, H.; Chung, J.S. The specific binding sites of eyestalk- and pericardial organ-crustacean hyperglycaemic hormones (CHHs) in multiple tissues of the blue crab, Callinectes sapidus. J. Exp. Biol. 2009, 212, 542-549. [CrossRef]

56. Chen, H.-Y.; Toullec, J.-Y.; Lee, C.-Y. The Crustacean Hyperglycemic Hormone Superfamily: Progress Made in the Past Decade. Front. Endocrinol. 2020, 11, 578958. [CrossRef] [PubMed]

57. Schägger, H.; Von Jagow, G. Tricine-sodium dodecyl sulfate-polyacrylamide gel electrophoresis for the separation of proteins in the range from 1 to $100 \mathrm{kDa}$. Anal. Biochem. 1987, 166, 368-379. [CrossRef]

58. Chen, H.Y.; Watson, R.D.; Chen, J.C.; Liu, H.F.; Lee, C.Y. Molecular characterization and gene expression pattern of two putative molt-inhibiting hormones from Litopenaeus vannamei. Gen. Comp. Endocrinol. 2007, 151, 72-81. [CrossRef] [PubMed]

59. Zhou, H.X.; Lyu, P.; Wemmer, D.E.; Kallenbach, N.R. Alpha helix capping in synthetic model peptides by reciprocal side chain-main chain interactions: Evidence for an $\mathrm{N}$ terminal "capping box". Proteins Struct. Funct. Bioinform. 1994, 18, 1-7. [CrossRef]

60. Lobley, A.; Whitmore, L.; Wallace, B. DICHROWEB: An interactive website for the analysis of protein secondary structure from circular dichroism spectra. Bioinformatics 2002, 18, 211-212. [CrossRef]

61. Chung, K.F.; Lin, H.C. Osmoregulation and Na, K-ATPase expression in osmoregulatory organs of Scylla paramamosain. Comp. Biochem. Physiol. A Mol. Integr. Physiol. 2006, 144, 48-57. [CrossRef] [PubMed]

62. Peterson, G.L. A simplified method for analysis of inorganic phosphate in the presence of interfering substances. Anal. Biochem. 1978, 84, 164-172. [CrossRef]

63. Holliday, C.W. Salinity-induced changes in gill Na, K-ATPase activity in the mud fiddler crab, Uca pugnax. J. Exp. Zool. Part A Ecol. Genet. Physiol. 1985, 233, 199-208. [CrossRef]

64. Tsai, J.R.; Lin, H.C. V-type H+-ATPase and Na+,K+-ATPase in the gills of 13 euryhaline crabs during salinity acclimation. J. Exp. Biol. 2007, 210, 620-627. [CrossRef] [PubMed]

65. Goddard, T.D.; Kneller, D.G. SPARKY 3; University of California: San Francisco, CA, USA, 2008.

66. Brunger, A.T. Version 1.2 of the Crystallography and NMR system. Nat. Protoc. 2007, 2, 2728. [CrossRef] [PubMed]

67. Oostenbrink, C.; Villa, A.; Mark, A.E.; van Gunsteren, W.F. A biomolecular force field based on the free enthalpy of hydration and solvation: The GROMOS force-field parameter sets 53A5 and 53A6. J. Comput. Chem. 2004, 25, 1656-1676. [CrossRef]

68. Laskowski, R.A.; MacArthur, M.W.; Moss, D.S.; Thornton, J.M. PROCHECK: A program to check the stereochemical quality of protein structures. J. Appl. Crystallogr. 1993, 26, 283-291. [CrossRef] 